\title{
Nematodes of Proceratophrys ararype (Anura: Odontophrynidae), an endemic frog from the Araripe Plateau, northeastern Brazil
}

\author{
Wilmara Mascarenhas $^{1 *(\infty)}$, Cicero R. Oliveira ${ }^{\circledR}$, Ronildo A. Benício $^{1 \oplus}$, Robson W. Ávila ${ }^{2}$ \& \\ Samuel C. Ribeiro ${ }^{3(1)}$ \\ ${ }^{1}$ Universidade Regional do Cariri, Programa de Pós-Graduação em Diversidade Biológica e Recursos \\ Naturais, Departamento de Química Biológica, Crato, CE, Brasil. \\ ${ }^{2}$ Universidade Federal do Ceará, Programa de Pós-Graduação em Ecologia e Recursos Naturais, \\ Departamento de Biologia, Fortaleza, CE, Brasil. \\ ${ }^{3}$ Universidade Federal do Cariri, Instituto de Formação de Educadores, Laboratório de Biologia e Ecologia de \\ Animais Silvestres, Brejo Santo, CE, Brasil. \\ *Corresponding author:wilmara.masc@gmail.com
}

\begin{abstract}
MASCARENHAS W., OLIVEIRA C.R., BENÍCIO R.A., ÁVILA R.W., RIBEIRO S.C. Nematodes of Proceratophrys ararype (Anura: Odontophrynidae), an endemic frog from the Araripe Plateau, northeastern Brazil. Biota Neotropica 21(3): e20201164. https://doi.org/10.1590/1676-0611-BN-2020-1164
\end{abstract}

\begin{abstract}
Parasites are an important component of the global biomass, having significant roles in several regulatory mechanisms in the ecosystem. Parasitism is one of the most common ecological interactions on the planet. Studies have shown that the helminth fauna of only $8 \%$ of amphibian species in Brazil have been studied, and this percentage is lower for the Odontophrynidae family, with only four of the 50 species kown to occur in Brazil having been investigated. Here, we present the helminth fauna of Proceratophrys ararype, an anuran endemic to the "Brejo de Altitude" Chapada do Araripe (Araripe Plateau), northeastern Brazil. The infection parameters analyzed were prevalence, mean intensity of infection and mean abundance of parasites. We used the Pearson's linear correlation coefficient to check the correlations between the abundance of the parasites with the snout-vent length (SVL) of hosts. To verify the degree of aggregation of parasites in hosts, we used the dispersion index. Out of 40 specimens examined, 19 specimens were infected with at least one parasite. The overall prevalence was $47.5 \%$ with a mean infection intensity of $18.93 \pm 10.77$. The endoparasitic community associated with $P$. ararype consisted of six species of parasites, with Falcaustra mascula having the highest prevalence (25\%). Most parasites had a uniform dispersion index in the hosts and their abundance was unrelated to host size. Here, we also present a compilation of all parasites associated with host species of the genus Proceratophrys from South America. Overall, we found 23 species of parasites associated with five host species (P. ararype, P. appendiculata, P. boiei, P. cristiceps, P. mantiqueira). Of these, two species of parasites (Oswaldocruzia mazzai and Strongyloides sp.) represent new records for the genus Proceratophrys. Our results demonstrate the lack of studies on amphibian helminth fauna and fill an important knowledge gap on the diversity of parasites of Proceratophrys ararype, an endemic frog from the Araripe Plateau, northeastern Brazil.
\end{abstract}

Keywords: Parasitism; Nematoda; Anuran

\section{Nematódeos de Proceratophrys ararype (Anura: Odontophrynidae), um sapo endêmico do Planalto do Araripe, nordeste do Brasil}

Resumo: Os parasitas são um componente importante da biomassa global, tendo papel significativo em vários mecanismos reguladores no ecossistema. O parasitismo é uma das interações ecológicas mais comuns no planeta. Estudos demonstraram que somente $8 \%$ da fauna de helmintos das espécies de anfíbios que ocorrem no Brasil foi estudada, sendo esta porcentagem mais baixa para a família Odontophrynidae, tendo sido investigadas apenas quatro das 50 espécies com ocorrência conhecida para o Brasil. Aqui, apresentamos a helmintofauna de Proceratophrys ararype, um anuro endêmico do "Brejo de Altitude" Chapada do Araripe, nordeste do Brasil. Os parâmetros de infecção analisados foram prevalência, intensidade média de infecção e abundância média de parasitas. Utilizamos o coeficiente de correlação linear de Pearson para verificar as correlações entre a abundância dos parasitas com o comprimento rostro-cloacal dos hospedeiros. Para verificar o grau de agregação dos parasitas nos hospedeiros, utilizamos o índice de dispersão. Dos 40 espécimes examinados, 19 estavam infectados com pelo menos um 
parasita. A prevalência geral foi de $47.5 \%$ com intensidade média de infecção de $18.93 \pm 10.77$. A comunidade endoparasitária associada a $P$. ararype constituiu de seis espécies de parasitas, com Falcaustra mascula tendo a maior prevalência (25\%). A maioria dos parasitas apresentaram índice de dispersão uniforme nos hospedeiros e sua abundância não esteve relacionada ao tamanho do hospedeiro. Aqui, nós também apresentamos uma compilação de todos os parasitas associados as espécies de hospedeiros do gênero Proceratophrys na América do Sul. No geral, nós encontramos 23 espécies de parasitas associadas a cinco espécies de hospedeiros ( . ararype, P. appendiculata, $P$. boiei, P. cristiceps, P. mantiqueira). Destas, duas espécies de parasitas (Oswaldocruzia mazzai e Strongyloides sp.) representam novos registros para o gênero Proceratophrys. Nossos resultados demonstram a carência de estudos sobre a helmintofauna de anfíbios e preenchem uma importante lacuna de conhecimento sobre a diversidade de parasitas de Proceratophrys ararype, um sapo endêmico do Planalto do Araripe, nordeste do Brasil.

Palavras-chave: Parasitismo; Nematoda; Anuros.

\section{Introduction}

Currently, 50 species of the Odontophrynidae family have been identified, with the genus Miranda-Ribeiro, 1920 making up 40 species registered in Brazil, Argentina, and Paraguay (Segalla et al. 2019, Mângia et al. 2020, Frost 2021). Species of the genus Proceratophry can be clumped into four species groups, based on the morphological similarities of adult individuals (Cruz et al. 2005, Prado \& Pombal 2008, Mângia et al. 2018): P. appendiculata, P. bigibbosa, P. boiei and $P$. cristiceps species groups. The $P$. cristiceps group comprises 14 species including $P$. ararype Mângia, Koroiva, Nunes, Roberto, Ávila, Sant'Anna, Santana \& Garda, 2018 (Ávila et al. 2011, Brandão et al. 2013, Mângia et al. 2018). This species was identified from specimens collected at the slope of Chapada do Araripe, a humid forest in the municipality of Crato, state of Ceará, northeastern Brazil. The distribution of this species is very restricted and limited to the slope of Chapada do Araripe (Mângia et al. 2018), a climate exception area in the Caatinga biome (Tabarelli \& Silva 2003), where local climatic conditions shape isolated systems (Vanzolini 1981, Borges-Nojosa \& Caramaschi 2003). Currently, information on the associated parasitic fauna of $P$. ararype is lacking.

The parasites are integral components of the global biomass, and one of the most common life forms on the planet (Kuris 2008, Poulin 2014, Oliveira et al. 2019). Among these parasites, the helminth fauna associated with amphibians is rich and diverse, despite being hidden within known biodiversity (Poulin 2014, Campião et al. 2014). The study of parasitic fauna is extremely important due to the roles they have in several regulatory mechanisms within the ecosystem, including the negative effects they have on their hosts such as anaemia, anorexia, reduced survival and fertility, and competition (Vitt \& Caldwell 2009, Matias et al. 2018). The study of these organisms not only contributes to our knowledge of animal diversity, but also clarifies the parasite dynamics of the host (Brooks \& Hoberg 2001, Galli et al. 2001, Poulin 2014), because the richness of parasite species can be assumed as a characteristic of the host, where rates of parasite colonization vary according to biology of hosts (Poulin 2014, Campião et al. 2015).

The latest checklist of helminths in South America stated that only about $8 \%$ of all amphibian species in Brazil have had their helminth fauna studied (Campião et al. 2014). Of the Proceratophrys genus, the helminth fauna of only four species has been studied: P. tupinamba Prado \& Pombal, 2008 (Boquimpani-Freitas et al. 2001), P. cristiceps Müller, 1883 (Teles et al. 2017, Silva et al. 2019, Sampaio et al. 2020), P. boiei Wied-Neuwied, 1824 (Toledo et al. 2018), and P. mantiqueira Mângia, Santana, Cruz \& Feio, 2014 (Almeida-Santos et al. 2017). As such, studies on parasitism are of fundamental importance for the conservation of hosts, especially those with a restricted distribution, in addition to filling knowledge gaps in host-parasite interactions, since hosts, in general, are more susceptible to local extinctions (Pontes \& Rocha 2011). Here we describe the composition and patterns of parasitic infection of helminths associated with P. ararype, an endemic frog from Chapada do Araripe, northeastern Brazil, and also present a compilation of all parasites associated with host species of the genus Proceratophrys from South America.

\section{Material and Methods}

This study was conducted on the slope of Chapada do Araripe in the state of Ceará, Brazil, within the limits of the Environmental Protection Area of Chapada do Araripe (APA Araripe). The owerall landscape is characterized of different vegetation types, with cut-outs of humid forest (sampled area), dry forest, Cerrado and Cerradão (Ferreira-Silva et al. 2019). Specimens of P. ararype were collected at night from the following locations: (i) Clube Recreativo Grangeiro

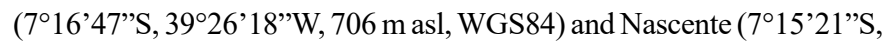
$39^{\circ} 28^{\prime} 08^{\prime \prime} \mathrm{W}, 739 \mathrm{~m}$ asl, WGS84), both in the municipality of Crato; (ii) Sítio Farias $\left(7^{\circ} 20^{\prime} 17^{\prime} \mathrm{S}, 39^{\circ} 233^{\prime} 43\right.$ ”W, $600 \mathrm{~m}$ asl, WGS84), in the municipality of Barbalha; and (iii) Sítio Aleixo ( $7^{\circ} 26^{\prime} 25^{\prime \prime} \mathrm{S}$, $39^{\circ} 05^{\prime} 27^{\prime}$ 'W, $946 \mathrm{~m}$ asl, WGS84) and Sítio Riachão (7²7’05”S, $39^{\circ} 06$ '38'W, $931 \mathrm{~m}$ asl, WGS84), both in the municipality of Missão Velha. The sampling period extended from November 7, 2018 to February 22, 2019.

A total of 40 Proceratophrys specimens were collected using the active search method (visual and auditory) (Bernarde 2012). Specimens were kept in individualized plastic containers and later euthanized by lethal injection of Lidocaine Hydrochloride (CFMV 2013). We measured the snout-vent lengths (SVL, in $\mathrm{mm}$ ) of hosts using a digital caliper Mitutoyo ${ }^{\circledR}$ (precision $0.01 \mathrm{~mm}$ ). Hosts were fixed according to Calleffo (2002) and deposited in the Herpetological Collection of the Regional University of Cariri, (URCA-H 15.579-15.616), Crato municipality and in the Herpetological Collection of the Federal University of Cariri (CHERP-UFCA 01-02), Brejo Santo municipality, both in the Ceará state, Brazil.

Specimens were necropsied and the organs (gastrointestinal tract, lungs, liver, kidneys and internal cavity) were harvested for analyses. Helminths were collected and fixed according to Amato et al. (1991) and Andrade (2000), the remaining food items were also accounted. For the identification of nematodes, we followed Vicente et al. (1991), in addition to recent studies on species descriptions. Analysed infection 
parameters include prevalence ( $\mathrm{P} \%$ ), mean infection intensity (MII), and mean parasite abundance (MA), as previously described by Bush et al. (1997). All the parasites were deposited in the Parasitology Collection of Universidade Federal do Cariri (CHERP-P-UFCA 01-29), Brejo Santo municipality, Ceará state, Brazil.

We used the Pearson's linear correlation coefficient (r) to assess correlation between parasite abundance with host snout-vent length (SLV, in $\mathrm{mm}$ ). The Mantel test was used to evaluate spatial autocorrelation between parasitic richness and sampled areas to verify if use the data as one or several parasite communities. The variance / mean ratio $(\mathrm{s} 2 / \overline{\mathrm{x}})$, also known as the dispersion index (ID), and the $\mathrm{k}$ parameter of the negative binomial distribution, were used to determine the degree of parasite aggregation within the hosts. The higher the $s / \bar{x}$ ratio, and the lower the value of parameter $\mathrm{k}$ (closer to zero), the higher the level of aggregation (Pielou 1977).

To compile literature data on parasites associated with host species of the genus Proceratophrys from South America, we conducted a wide search in different databases (e.g., Google Academic, Scielo, Scopus) and in bibliographic reviews on the topic (e.g., Campião et al. 2014).

\section{Ethical Standards}

The authors assert that all procedures contributing to this study comply with the ethical standards of the relevant national and institutional guides on the care and use of laboratory animals. The study was approved by the Ethical Committee of Universidade Regional do Cariri (CEUA/URCA, process number 00260/2016.1) and Instituto Chico Mendes de Conservação da Biodiversidade (ICMBio/SISBIO, number 66099-2).

\section{Results}

We examined $40 P$. ararype specimens, of these 19 (five females and 14 males) were parasitized by 511 helminths, with a total prevalence of $47.5 \%$ and mean infection intensity of $18.93 \pm 10.77$. The $P$. ararype endoparasitic community was comprised of six parasite species: Aplectana membranosa Schneider, 1866, Falcaustra mascula Rudolphi, 1819, Oswaldocruzia mazzai Travassos, 1935, Physaloptera sp., Raillietnema spectans Gomes, 1964 and Strongyloides sp. Falcaustra mascula had the highest prevalence $(25 \%)$ and $R$. spectans had the lowest prevalence $(2.5 \%)$, the highest abundance rate (6.5), and a mean intensity of (260.0) (Table 1).

There was no correlation between parasite general abundance and host snout-vent length $\left(\mathrm{R}^{2}=0.01, \mathrm{p}=0.43\right)$, when analyzing the most prevalent parasite species individually, we also found no significant correlation between parasite abundance and SVL: A. membranosa $\left(\mathrm{R}^{2}=0.13, \mathrm{p}=0.79\right)$, Physaloptera $\mathrm{sp} .\left(\mathrm{R}^{2}=0.34\right.$, $p=0.56)$, and F. mascula $\left(\mathrm{R}^{2}=0.18, \mathrm{p}=0.61\right)$. Additionally, spatial autocorrelation was not observed between sample areas and parasitized individuals $\left(\mathrm{R}^{2}=0.3545, \mathrm{p}=0.11667\right)$. Examination of pattern dispersion revealed that most helminth species had a uniform distribution among hosts (Table 2), that is, the growth in the number of infected individuals is directly proportional to the prevalence of infection.

In our literature data compilation, we found, in general, five host species (P. ararype, P. appendiculata, P. boiei, P. cristiceps, P. mantiqueira) being parasitized by 23 helminth species. Proceratophrys cristiceps was the host species with the highest number of associated parasitic helminths ( $\mathrm{n}=$ 10 spp.). Physaloptera sp. was the only helminth common to all studied Proceratophrys species (Table 3 ). In this study we identified two additional species (O. mazzai and Strongyloides sp.) (Figure 1A, B) registered for the genus Proceratophrys.

\section{Discussion}

The genus Proceratophrys has 23 species of registered parasites (Campião et al. 2014, Almeida-Santos et al. 2017, Teles et al. 2017, Toledo et al. 2018, Silva et al. 2019, Sampaio et al. 2020, this study). Like observations made in previous studies, we observed a particular parasitic community per host species, with Physaloptera sp. being the only helminth common to all studied Proceratophrys species (Table 3). This result could be due to the geographical locations of each species, which have different environmental conditions, and thereby affecting the composition and richness of biotic factors (Poulin \& Krasnov 2010). On the other hand, P. cristiceps, which has a wide geographical distribution (Mângia et al. 2020), was the best studied species (Teles et al. 2017, Müller et al. 2018, Silva et al. 2019, Sampaio et al. 2020) and with the highest number of associated parasitic helminths (n $=10$ spp.). This result emphasizes that habitat, along with the biology, life history of the host and study effort, can influence parasitic composition (Campião et al. 2015).

Species of the genus Aplectana are usually found infecting the large intestine of reptiles and amphibians, have a direct life cycle, and actively infect their hosts (Travassos 1931, Anderson 2000, Campião et al. 2014, Lins et al. 2017). This genus has been observed in four species of the Odontophrynidae family: Proceratophrys tupinamba and $P$. boiei, infected by $A$. delirae Fabio, 1971 (Boquimpani-Freitas et al. 2001, Klaion et al. 2011), and P. cristiceps (Silva et al. 2019, Sampaio et al. 2020) and Odontophrynus americanus Duméril \& Bibron, 1841, infected by A. membranosa (Lent \& Freitas 1948). In this

Table 1. Prevalence (P), mean intensity of infection (MII) with standard error (SD), mean abundance (MA), and site of infection (SI) of nematodes found in Proceratophrys ararype, Chapada do Araripe, northeastern Brazil.

\begin{tabular}{lcccc}
\hline Parasite & P $(\mathbf{\%})$ & MII \pm EP & MA \pm EP & SI \\
\hline Aplectana membranosa & 15 & $31.3 \pm 26.8$ & $4.7 \pm 7.9$ & large intestine \\
Falcaustra mascula & 25 & $1.7 \pm 0.3$ & $0.43 \pm 0.9$ & large intestine, small intestine \\
Oswaldocruzia mazzai & 7.5 & $1.3 \pm 0.3$ & $0.1 \pm 0.6$ & small intestine \\
Physaloptera sp. & 12.5 & $3.4 \pm 0.6$ & $0.43 \pm 1.5$ & stomach \\
Raillietnema spectans & 2.5 & 260.0 & 6.5 & large intestine \\
Strongyloides sp. & 7.5 & $8.3 \pm 4.4$ & $0.63 \pm 9.2$ & small intestine \\
\hline
\end{tabular}


Table 2. Dispersion index (ID) values, k exponent of the negative binomial distribution (k), and parasite distribution in Proceratophrys ararype, Chapada do Araripe, northeastern Brazil.

\begin{tabular}{lccc}
\hline Parasite & ID & k & Distribution \\
\hline Aplectana membranosa & 164.89 & 0.19 & Aggregate \\
Falcaustra mascula & 0.56 & -3.55 & Uniform \\
Oswaldocruzia mazzai & 0.25 & -1.77 & Uniform \\
Physaloptera sp. & 0.67 & -10.50 & Uniform \\
Raillietnema spectans & 0.00 & -261.00 & Uniform \\
Strongyloides sp. & 10.24 & 0.90 & Aggregate \\
\hline
\end{tabular}

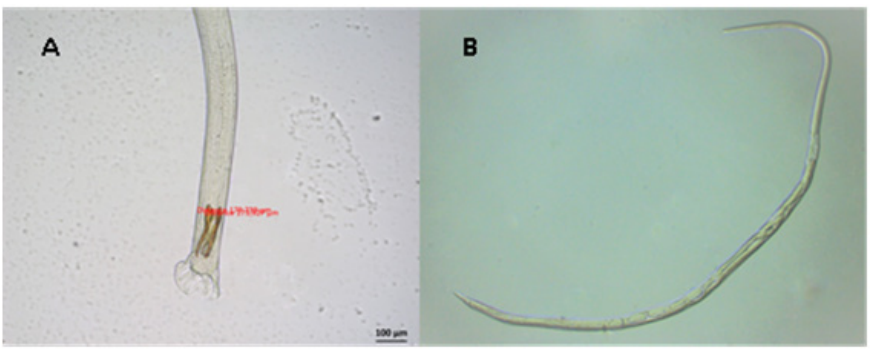

Figure 1. New parasite records for Proceratophrys ararype. (A) Oswaldocruzia mazzai, posterior view with taxonomic diagnostic characteristics (spicula and copulating bag; in red, measure of the spicula). (B) Strongyloides sp., total view with taxonomic diagnostic characteristics (prolonged esophagus and ovary disposition).

study, A. membranosa has also been registered for $P$. ararype, and it is the parasite with the second highest prevalence, abundance, and overall mean intensity. High indices were also found for Leptodactylus syphax $(\mathrm{MII}=250.4)$ (Lins et al. 2017) and $P$. cristiceps $(\mathrm{MII}=65.5$; cited as $P$. aridus by Silva et al. 2019). High infection values can be explained by the low host vagility that contributes to increased parasite transmission (Mcalpine 1997). Additionally, A. membranosa females produce large amounts of infective larvae in the environment, increasing infection rates (Lins et al. 2017).

Falcaustra mascula has been shown to infect the small and large intestine of several amphibians (e.g., Campião et al. 2014, Toledo et al. 2015, Toledo et al. 2018, Silva et al. 2019). Little is known about its modes of transmission. Anderson (2000) suggested that the larvae reach its third development stage and then infect an intermediate invertebrate host, which in turn is ingested by amphibians. Toledo et al. (2018) found that among all host parasites $F$. mascula had the highest prevalence rate in Boana faber (Wied-Neuwied, 1821) $(\mathrm{P}=9.1 \%)$, Leptodactylus latrans (Steffen, 1815) $(\mathrm{P}=13.9 \%)$, and Rhinella icterica (Spix, 1824) $(\mathrm{P}=33.3 \%)$. Therefore, our result for prevalence rate $(\mathrm{P}=25 \%)$ is consistent with the literature data. One plausible explanation for the high infection rates observed for this parasite is that the intermediate host is an arthropod, which is a type of prey that is extensively consumed by anurans.

Oswaldocruzia mazzai have been shown to infect a variety of anuran hosts (e.g., Campião et al. 2014, Teles et al. 2015, Alcantara et al. 2018, Oliveira et al. 2019) but our study is the first to record a species of the genus Proceratophrys as a host of $O$. mazzai. The low host specificity is usual for some groups of helminths (Campião et al. 2015, Oliveira et al. 2019). The great diversity of hosts registered for $O$. mazzai is related to the direct life cycle, and the simple mode of transmission that can occur by ingesting eggs or larval penetration into the host's skin (Anderson 2000).
Nematodes of the Physaloptera genus have a worldwide geographical distribution and have been recorded in several classes of terrestrial vertebrates, including felines (Ogassawara 1986), rodents (Tung et al. 2009), lizards (Da Silva et al. 2008, Cabral et al. 2018) and anurans (Da Graça et al. 2017). This parasite was usual for all studied Proceratophrys species (see Table 3). In amphibians, this parasite is usually found in larval stage, making it difficult to identify at the species level, and is suggestive that these amphibians are not definitive hosts. Although there is not enough data about its life cycle, nematodes of this genus are known to use insects during their intermediate phase (Anderson 2000). Additionally, the acquisition of Physaloptera by anuran hosts occurs through the ingestion of infected insects, mainly Orthoptera (Klaion et al. 2011).

The Strongyloides genus has a low specificity, with records for several classes, including mammals (occasionally humans), birds, reptiles, and amphibians (Little 1966, Urquhart et al. 1998). Although there is a lack of detailed biology on this parasite, it is known to have a direct or indirect life cycle, with the former being the most usual (Santos et al. 2010). The infection occurs on land through skin penetration or ingestion of infected preys (Mati \& Melo 2014, Sulieman et al. 2015). Even though this nematode infects several amphibian species (Campião et al. 2014, Sulieman et al. 2015), this is the first record of the genus Strongyloides acting as a parasite for species of the Odontophrynidae family.

The parasite Raillietnema spectans was initially described in the large intestine of leptodactylids and bufonids (Alcântara et al. 2018), and it has been registered for several other species: Rhinella crucifer (Wied-Neuwied, 1821), R. icterica and Leptodactylus latrans (Campião et al. 2014), Pleurodema diplolister (Peters, 1870) (Teles et al. 2015), Physalaemus albifrons (Spix, 1824), P. cicada Bokermann, 1966 P. cuvieri Fitzinger, 1826 (Oliveira et al. 2019), and Dermatonotus muelleri (Boettger, 1885) (Alcantara et al. 2018). This parasite is known to presents a direct life cycle and transmission that occurs via ingestion or penetration of larvae in the skin (Anderson 2000). In this study, R. spectans had the lowest prevalence, contrary to the results from Alcântara et al. (2018) and Oliveira et al. (2019). This low prevalence may be related to host phylogeny, which is reflected in the structuring of parasitic interactions (Krasnov et al. 2012), or geographical, biological, and life history effects on the host, which can influence parasitic composition (Campião et al. 2015).

Helminths registered for the genus Proceratophrys are usually found in other taxa of amphibians, and therefore can be considered generalists (Campião et al. 2014, Müller et al. 2018, Silva et al. 2019). Nevertheless, studies on Procetatophrys cristiceps (Teles et al. 2017, Müller et al. 2018, Silva et al. 2019), and P. ararype (this study), in northeastern Brazil, and on P. boiei, P. mantiqueira and P. tupinamba, in humid forests of southeastern Brazil (Boquimpani-Freitas et al. 2001, Klaion et al. 2011, Almeida-Santos et al. 2017, Toledo et al. 2018), show a greater similarity between helminth communities in locally close hosts. These results suggest that geographic distribution of the host, and the different local conditions, could influence the composition of helminth fauna.

We did not find correlation between parasitism and host size. This result contrasts with those found for the genus Leptodactylus, where body size accounted for $17 \%$ of the variation in species composition, compared to the $3 \%$ accounted for the host's habitat (Campião et al. 2016a). However, our results were similar to those described by Oliveira et al. (2019) for Physalaemus species. This similarity between the results may be due to the smaller size variation, when species are analysed 
Table 3. Helminths associated with the genus Proceratophrys Miranda-Ribeiro, 1920 from South America.

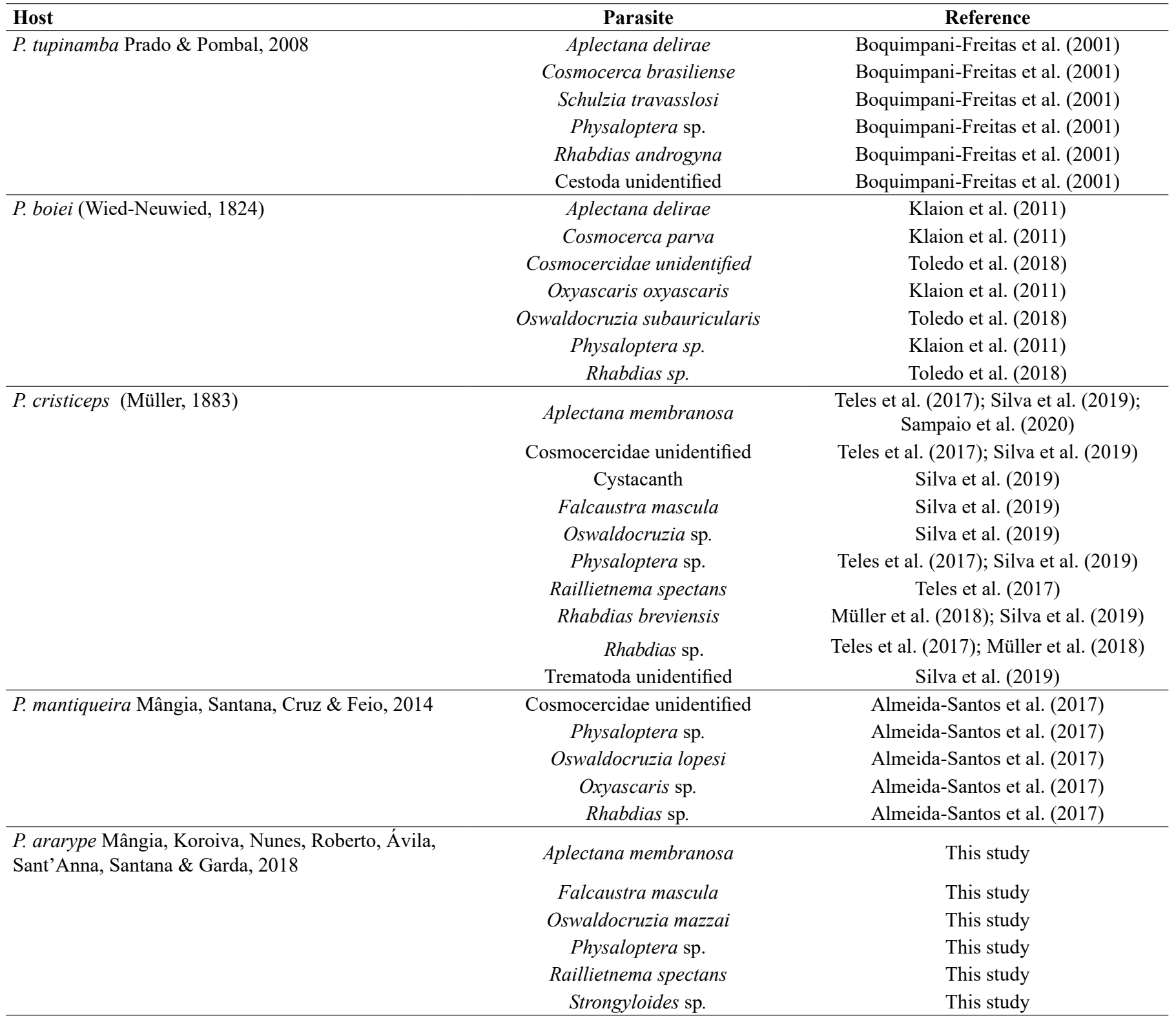

separately, as observed for Physalaemus by Oliveira et al. (2019) and for Proceratophrys in this study, different from that observed in the genus Leptodactylus by Campião et al. (2016a). Thus, the diversity of parasites in Proceratophrys ararype does not appear to be influenced by the size of the hosts.

The dispersion of parasites in Procetatophrys ararype was uniform for most species (Table 2). One of the most usual characteristics of parasitic infections in populations of vertebrate hosts is aggregation, because these infections rarely happen or are due to the high lethality in infected hosts, which cannot survive for long periods (Von Zuben 1997). Therefore, the uniform dispersion model, predominant in the helminth species of this study, may be due to parasite mortality, a process dependent on the density and mortality of the host induced by the parasite. Additionally, regular or uniform distribution is also observed if there is strict competition between individuals, or if there is positive antagonism, causing a constant minimum distance between individuals (Odum \& Barrett 2008).
Anurans have the supracommunity pattern of diversified generalist helminth parasites with low host specificity and wide distribution (Campião et al. 2014). Due to the increase in studies conducted on this topic (e.g., Campião et al. 2016a, b, Lins et al. 2017, Teles et al. 2017, Leivas et al. 2018, Alcantara et al. 2018, Oliveira et al. 2019), it is quite common to find new records of hosts containing parasites that have not previously been described for the species (e.g., Aguiar et al. 2014, Silva et al. 2019). In this study, we present new records on species of parasites (O. mazzai and Strongyloides sp.) for the genus Proceratophrys, increasing the total number to 21 helminths. Additionally, all helminth species found represent their first records for Procetatophrys ararype, a frog endemic to the Brejo de Altitude Chapada do Araripe, Northeastern Brazil.

\section{Acknowledgements}

We would like to thank Raimundo Marques de Almeida, Paula Danielly Figueiredo Silva, and Teresinha Pereira Machado Roberto for 
granting access to the collection site; to Editage (www.editage.com) for English language editing.

We thank the Coordenação de Aperfeiçoamento de Pessoal de Nível Superior - CAPES for the scholarship granted (Financial Code 001 and 88882.454307/2019-01); the Fundação Cearense de Apoio ao Desenvolvimento Científico e Tecnológico - FUNCAP for productivity scholarship (Code BP3-0139-00323.01.00/18 and BP4 00172-00223.01.01/20); the Universidade Federal do Cariri-UFCA for Costing Notice for Research Projects; and the Conselho Nacional de Desenvolvimento Científico e Tecnológico CNPq for research grants (RWA, 305988/2018-2; RAB, 155556/2018-5).

\section{Author Contributions}

Wilmara Mascarenhas: Contribution to data collection; contribution to identification of parasites and amphibians; contribution to data analysis and interpretation; contribution to manuscript preparation and critical revision

Cicero R. Oliveira: Contribution to data collection; contribution to identification of parasites and amphibians; contribution to data analysis and interpretation; contribution to manuscript preparation and critical revision.

Ronildo A. Benício: Contribution to data analysis and interpretation; contribution to manuscript preparation and critical revision.

Robson W. Ávila: Contribution to identification of parasites and amphibians; contribution to manuscript preparation and critical revision.

Samuel C. Ribeiro: Contribution to data collection; contribution to data analysis and interpretation; contribution to manuscript preparation and critical revision.

\section{Conflicts of Interest}

The authors declare that they have no conflict of interest related to the publication of this manuscript.

\section{References}

AGUIAR, A., MORAIS, D.R., PYLES, P.C. \& SILVA, R.J. 2014. Evaluation of helminths associated with 14 amphibian species from a neotropical island near the southeast coast of Brazil. Herpetol. Rev. 2:227-236.

ALCANTARA, E.P., FERREIRA-SILVA, C., SILVA, L.A.F., LINS, A.G.S., ÁVILA, R.W., MORAIS, D.H. \& SILVA, R.J. 2018. Helminths of Dermatonotus muelleri (Anura: Microhylidae) from Northeastern Brazil. J. Parasitol. 104:550-556.

ALMEIDA-SANTOS, M., SIQUEIRA, C.C., ANJOS, L.A., VAN SLUYS, M., ROCHA, C.F.D. 2017. Ecological aspects of the horned leaf-frog Proceratophrys mantiqueira (Odontophrynidae) in an Atlantic Rainforest area of southeastern Brazil. Salamandra 53:413-422.

AMATO, J.F.R., BOEGER, W.A. \& AMATO, S.B. 1991. Protocolos para laboratório-coleta e processamento de parasitos de pescado. Imprensa Universitária, Universidade Federal Rural do Rio de Janeiro, Seropédica.

ANDERSON R.C. 2000. Nematode parasites of vertebrates, their development and transmission. 2 ed. CABI Publishing, Wallingford.

ANDRADE, C.M. 2000 Meios e soluções comumente empregados em laboratórios. Editora Universidade Rural, Rio de Janeiro.

ÁVILA, R.W., KAWASHITA-RIBEIRO, R.A. \& MORAIS, D.H. 2011. A new species of Proceratophrys (Anura: Cycloramphidae) from western Brazil. Zootaxa 2890:20-28.

BERNARDE, P.S. 2012. Anfíbios e répteis: introdução ao estudo da herpetofauna brasileira. 1 ed. Anolis Books, Curitiba.

BOQUIMPANI-FREITAS, I.D., VRCIBRADIC, D., VICENTE, J.J., BURSEY, C.R., ROCHA, C.F.D. \& SLUYS, M.V. 2001. Helminths of the horned leaf frog, Procetatophrys appendiculata, from southeastern Brazil. J. Helminthol. 75:233-236
BORGES-NOJOSA, D.M. \& CARAMASCHI, U. 2003: Composição e análise comparativa da diversidade e das afinidades biogeográficas dos lagartos e anfisbenídeos (Squamata) dos brejos nordestinos. In: Ecologia e conservação da Caatinga (I. Leal, M. Tabarelle \& J.M.C. Silva eds). UFPE, Recife, p.489-540.

BRANDÃO, R.A., CARAMASCHI, U., VAZ-SILVA, W. \& CAMPOS, L.A. 2013. Three new species of Proceratophrys Miranda-Ribeiro 1920 from Brazilian Cerrado (Anura, Odontophrynidae). Zootaxa 3750:321-347. http:// dx.doi.org/10.11646/zootaxa.3750.4.2 (last access on 22/08/2018)

BROOKS, D.R. \& HOBERG, E.P. 2001. Parasite systematics in the 21st century: opportunities and obstacles. Trends Parasitol. 17:273-275. https://doi. org/10.1016/S1471-4922(01)01894-3 (last access on 26/11/2019)

BUSH, A.O., LAFFERTY, K.D., LOTZ, J.M. \& SHOSTAK, A.W. 1997. Parasitology meets ecology on its own terms: Margolis et al. revisited. J. Parasitol. 83:575-583.

CABRAL, A.N., TELES, D.A., BRITO, S.V., ALMEIDA, W.O., DOS ANJOS, L.A., GUARNIERI, M.C. \& RIBEIRO, S.C. 2018. Helminth parasites of Mabuya arajara Rebouças-Spieker, 1981 (Lacertilia: Mabuyidae) from Chapada do Araripe, northeastern Brazil. Parasitol. Res. 117:1185-1193. https://doi.org/10.1007/s00436-018-5797-7 (last access on 16/04/2020)

CALLEFFO, M.E.V. 2002. Anfíbios. In: Técnicas de coleta e preparação de vertebrados para fins científicos e didáticos (P. Auricchio \& M.G. Salomão eds). Instituto Pau Brasil de História Natural, São Paulo, p.45-73.

CAMPIÃO, K.M., RIBAS, A.C.A., MORAIS, D.H., DIAS, O.T., SILVA, R.J. \& TAVARES, L.E.R. 2015. How many parasites species a frog might have? Determinants of parasite diversity in south american anurans. PloS one 10:e0140577. https://doi.org/10.1371/journal.pone.0140577 (last access on $08 / 09 / 2018$ )

CAMPIÃO, K.M., MORAIS, D.H., DIAS, O.T., AGUIAR, A., TOLEDO, G., TAVARES, L.E.R., \& DA SILVA, R.J. 2014. Checklist of helminth parasites of amphibians from south america. Zootaxa 3843:1-93. http://dx.doi. org/10.11646/zootaxa.3843.1.1 (last access on 03/09/2018)

CAMPIÃO, K.M., DIAS, O.T., SILVA, R.J., FERREIRA, V.L. \& TAVARES, L.E.R. 2016a: Living apart and having similar trouble: are frog helminth parasites determined by the host or by the habitat? Can. J. Zool. 94:761-765. https://doi.org/10.1139/cjz-2016-0066 (last access on 02/10/2018)

CAMPIÃO, K.M., SILVA, I.C.O., DALAZEN, G.T., PAIVA, F. \& TAVARES, L.E.R. 2016b. Helminth parasites of 11 anuran species from the pantanal wetland, Brazil. Comp. Parasitol. 83:92-100. https://doi.org/10.1654/15252647-83.1.92 (last access on 12/11/2019)

CONSELHO FEDERAL DE MEDICINA VETERINÁRIA - CFMV 2013. Métodos de eutanásia. In: Guia brasileiro de boas práticas de eutanásia em animais (Comissão de ética, Bioética e bem-estar animal - CFMV, eds). ASCOM/CFMV, Brasília, p.28-29.

CRUZ, C.A.G., PRADO, G.M. \& IZECKSOHN, E. 2005. Nova espécie de Proceratophrys Miranda-Ribeiro, 1920 do sudeste do Brasil (Amphibia, Anura, Leptodactylidae). Arq. Mus. Nac. 63:289-295.

DA GRAÇA, R.J., ODA, F.H., LIMA, F.S., GUERRA, V., GAMBALE, P.G. \& TAKEMOTO, R.M. 2017. Metazoan endoparasites of 18 anuran species from the mesophytic semideciduous Atlantic Forest in southern Brazil. J. Nat. Hist. 51:705729. https://doi.org/10.1080/00222933.2017.1296197 (last access on 29/09/2019)

DA SILVA, A.S., ZANETTE, R.A., TOCHETTO, C., OLIVEIRA, C.B., SOARES, J.F., OTTO, M.A. \& MONTEIRO, S.G. 2008. Parasitismo por Physaloptera sp., Kalicephalus sp. e Cryptosporidium sp. em lagarto (Tupinambis teguixin) no Rio Grande do Sul, Brasil. Rev. Bras. Zoociência 10:269-272.

FERREIRA-SILVA, C., RIBEIRO, S.C., ALCANTARA, E.P. \& ÁVILA, R.W. 2019. Natural history of the rare and endangered snake Atractus ronnie (Serpentes: Colubridae) in northeastern Brazil. Phyllomedusa 18:77-87.

FROST, D.R. 2021. Amphibian species of the world: An online reference. Versão 6.1. New York: American Museum of Natural History. Disponível em $<\mathrm{https}: / /$ amphibiansoftheworld.amnh.org/index.php $>$ (last access on 04/03/2021).

GALLI, P., CROSA, G., MARINIELLO, L., ORTIS, M. \& D'AMELIO, S. 2001. Water quality as a determinant of the composition of fish parasites communities. Hydrobiologia 452:173-179. https://doi. org/10.1023/A:1011958422446 (last access on 03/12/2019)

KLAION, T., GOMES, M.A., TAVARES, L.E.R., ROCHA, C.F.D. \& SLUYS, M.V. 2011. Diet and nematode infection in Proceratoprhys boiei (Anura: Cycloramphidae) from two Atlantic Rainforest remnants in southeastern Brazil. An. Acad. Bras. Ciênc. 83:1303-1312. https://doi.org/10.1590/ S0001-37652011000400017 (last access on 04/06/2019) 
KRASNOV, B.R., FORTUNA, M.A., MOUILLOT, D., KHOKHLOVA, I.S., SHENBROT, G.I. \& POULIN, R. 2012. Phylogenetic signal in module composition and species connectivity in compartmentalized host-parasite networks. Am. Nat. 179:501-511. https://doi.org/10.1086/664612 (last access on 01/11/2019)

KURIS, A.M. 2008. Ecosystem energetic implications of parasite and free-living biomass in three estuaries. Nature 454:515-518. https://doi.org/10.1038/ nature 06970 (last access on 09/12/2019)

LEIVAS, P.T., LEIVAS, F.W.T. \& CAMPIÃO, K.M. 2018. Diet and parasites of the anuran Physalaemus cuvieri Fitzinger, 1826 (Leiuperidae) from an Atlantic Forest fragment. Herpetol. Notes 11:109-113.

LENT, H. \& FREITAS, J.F.T. 1948. Una colecao de nematodeos, parasitos de vertebrados, do museu de Historia Natural de Montevideo. Mem. Inst. Oswaldo Cruz 46:1-71. http://dx.doi.org/10.1590/s0074-02761948000100001 (last access on 12/10/2019)

LINS, A.G.S., AGUIAR, A., MORAIS, D.H., DA SILVA, L.A.F., ÁVILA, R.W. \& SILVA, R.J. 2017. Helmintofauna de Leptodactylus syphax (Anura: Leptodactylidae) do bioma da Caatinga, nordeste do Brasil. Rev. Bras. Parasitol. Vet. 26:74-80. https://doi.org/10.1590/s1984-29612017013 (last access on 02/09/2019)

LITTLE, M.D. 1966. Seven new species of Strongyloides (Nematoda) from Louisiana. J. Parasitol. 52:85-97. https://doi.org/10.2307/3276397 (last access on 29/10/2019)

MÂNGIA, S., KOROIVA, R., NUNES, P.M.S., ROBERTO, I.J., ÁVILA, R.W. SANT'ANNA, A.C., SANTANA, D.J. \& GARDA, A.A. 2018. A new species of Proceratophrys (Amphibia: Anura: Odontophrynidae) from the Araripe plateau, Ceará state, northeastern Brazil. Herpetologica 74:255-268. https://doi. org/10.1655/Herpetologica-D-16-00084.1 (last access on 04/08/2018)

MÂNGIA, S., OLIVEIRA, E.F., SANTANA, D.J., KOROIVA, R., PAIVA, F. \& GARDA, A.A. 2020. Revising the taxonomy of Proceratophrys MirandaRibeiro, 1920 (Anura: Odontophrynidae) from the Brazilian semiarid Caatinga: morphology, calls and molecules support a single widespread species. J. Zool. Syst. Evol. Res. 00:1-22. https://doi.org/10.1111/jzs.12365 (last access on 15/03/2020)

MATI, V.L.T. \& MELO, A.L. 2014. Some aspects of the life history and morphology of Strongyloides ophidiae Pereira, 1929 (Rhabditida: Strongyloididae) in Liophis miliaris (Squamata: Dipsadidae). Neotrop. Helminthol. 8:203-216.

MATIAS, C.S.L., FERREIRA-SILVA, C., SOUSA, J.G.G. \& ÁVILA, R.W. 2018 Helminths infecting the black false boa Pseudoboa nigra (Squamata: Dipsadidae) in northeastern Brazil. Acta. Herpetol. 13:171-175. https://doi.org/10.13128/ Acta_Herpetol-23366 (last access on 07/09/2019)

MCALPINE, D.F. 1997. Helminth communities in bullfrogs (Rana catesbeiana), green frogs (R. clamitans), and leopard frogs (R. pipiens) from new brunswick, Canada. Can. J. Zool. 75:1883-1890. https://doi.org/10.1139/ z97-818 (last access on 04/07/2019)

MÜLLER, M.I., MORAIS, D.H., COSTA-SILVA, G.J., AGUIAR, A., ÁVILA, R.W. \& SILVA, R.J. 2018. Diversity in the genus Rhabdias (Nematoda, Rhabdiasidae): evidence for cryptic speciation. Zoologica Scripta 47:595607. https://doi.org/10.1111/zsc.12304 (last access on 11/09/2019)

ODUM, E.P. \& BARRETT, G.W. 2008. Fundamentos de Ecologia. $5^{\mathrm{a}}$ ed. Cengage Learning, São Paulo.

OGASSAWARA, S., BENASSI, S., LARSSON, C.E.,LEME, P.T.Z. \& HAGIWARA, M.K. 1986. Prevalência de infecções helmínticas em gatos na cidade de São Paulo. Rev. Fac. Med. Vet. Zootec. Univ. S. Paulo 23:145-149. https://doi. org/10.11606/issn.2318-3659.v23i2p145-149 (last access on 03/06/2019)

OLIVEIRA, C.R., ÁVILA, R.W. \& MORAIS, D.H. 2019. Helminths associated with three Physalaemus species (Anura: Leptodactylidae) from Caatinga Biome, Brazil. Acta Parasitol. 64:205-212. https://doi.org/10.2478/s11686018-00022-88 (last access on 22/08/2019)

PIELOU, E.C. 1977. Mathematical ecology. Wiley-Interscience Publication. New-York

PONTES, J.A.L. \& ROCHA, C.F.D. 2011. Leaf litter amphibians of brazilian atlantic rainflorest: current status of knowledge. Oecologia Aust. 15:750-761 http://dx.doi.org/10.4257/oeco.2011.1504.01 (last access on 04/03/2021)

POULIN, R. 2014. Parasite biodiversity revisited: frontiers and constraints. Int J. Parasitol. 44:581-589.

POULIN, R. \& KRASNOV, B.R. 2010. Similarity and variability of parasite assemblages across geographical space. In: The biogeography of hostparasite interactions (S. Morand \& B.R. Krasnov, eds). Oxford University, New York, p.115-128.

PRADO, G.M. \& POMBAL JR, J.P. 2008. Espécies de Proceratophrys MirandaRibeiro, 1920 com apêndices palpebrais (Anura; Cycloramphidae). Arq Zool. 39:1-85. https://doi.org/10.11606/issn.2176-7793.v39i1p1-85 (last access on 12/08/2018)
SAMPAIO, N.K.S, SILVA, E.G., PINTO, C.L.M., DUARTE, R.G., TEIXEIRA, A.A.M., ALMEIDA, W.O. \& BRITO, S.V. 2020. Proceratophrys aridus Endoparasites. Herpetol. Rev. 51:302.

SANTOS, K.R., CARLOS, B.C., PADUAN, K.S., KADRI, S.M., BARRELLA, T.H., AMARANTE, M.R.V., RIBOLLA, P.E.M. \& SILVA, R.J. 2010 Morphological and molecular characterization of Strongyloides ophidiae (Nematoda, Strongyloididae). J. Helminthol. 84:136-142. https://doi. org/10.1017/S0022149X09990381 (last access on 04/10/2019)

SEGALlA, M.V., CARAMASCHI, U., CRUZ, C.A.G., GARCIA, P.C.A., GRANT, T., HADDAD, C.F.B., SANTANA, D.J., TOLEDO, L.F. \& LANGONE, J.A. 2019. Lista de espécies brasileiras-Brazilian Amphibians: List of Species. Herpetologia Brasileira 8:65-96.

SILVA, C.S., ALCANTARA, E.P., SILVA, R.J., ÁVILA, R.W. \& MORAIS, D.H 2019. Helminths parasites of the frog Proceratophrys aridus Cruz, Nunes, and Juncá, 2012 (Anura: Odontophrynidae) in a semiarid region, Brazil Neotrop. Helminthol. 13:169-179.

SULIEMAN, Y., AFIFI, A., AWAD, H.M. \& PENGSAKUL, T. 2015. Helminth parasites of the subdesert toad, Amietophrynus (Bufo) xeros (Anura Bufonidae). Int. J. Res. - Granthaalayah 3:75-83.

TABARELLI, T. \& SILVA, J.M.C. 2003. Áreas e ações prioritárias para a conservação da biodiversidade da caatinga. In: Ecologia e conservação da caatinga (I.R. LEAL, M. TABARELLI, J.M.C. SILVA \& M.L.B. BARROS, eds). UFPE, Recife, p.777-796.

TELES, D.A., SOUSA, J.G.G., TEIXEIRA, A.A.M., SILVA, M.C., OLIVEIRA, R.H., SILVA, M.R.M. \& ÁVILA, R.W. 2015. Helminths of the frog Pleurodema diplolister (Anura, Leiuperidae) from the Caatinga in Pernambuco state, northeast Brazil. Braz. J. Biol. 75:251-253. https://doi. org/10.1590/1519-6984.08513 (last access on 12/09/2019)

TELES, D.A.,BRITO, S.V.,ARAÚJO-FILHO, J.A., TEIXEIRA,A.A.M., RIBEIRO, S.C., MESQUITA, D.O. \& ALMEIDA, W.O. 2017. Nematode parasites of Proceratophrys aridus (Anura: Odontophrynidae), an endemic frog of the Caatinga domain of the neotropical region in Brazil. Herpetol. notes 10:525-527.

TOLEDO, G.M., MORAIS, D.H., SILVA, R.J. \& ANJOS, L.A. 2015. Helminth communities of Leptodactylus latrans (Anura: Leptodactylidae) from the Atlantic rainforest, south-eastern Brazil. J. Helminthol. 89:250-254. https:// doi.org/10.1017/S0022149X1300076X (last access on 12/09/2019)

TOLEDO, G.M., SCHWARTZ, H.O., NOMURA, H.A.Q., AGUIAR, A., VELOTA, R.A.M.V., DA SILVA, R.J. \& ANJOS, L.A. 2018. Helminth community structure of 13 species of anurans from Atlantic rainforest remnants, Brazil. J. Helminthol. 92:438-444. https://doi.org/10.1017/ S0022149X17000608 (last access on 12/09/2019)

TRAVASSOS, L. 1931. Pesquisas helmintologicas realizadas em Hamburgo. IX Ensaio monographico da familia Cosmocercidae Trav., 1925 (Nematoda). Mem. Inst. Oswaldo Cruz 25:237-298.

TUNG, K.C., HSIAO, F.C., YANG, C.H., CHOU, C.C., LEE, W.M., WANG, K.S. \& LAI, C.H. 2009. Surveillance of endoparasitic infections and the first report of Physaloptera sp. and Sarcocystis spp. in farm rodents and shrews in central Taiwan. J. Vet. Med. Scien. 71:43-47. https://doi.org/10.1292 jvms.71.43 (last access on 04/10/2019)

URQUHART, G.M., ARMOUR, J., DUNCAN, J.L. \& JENNINGS, F.W. 1998. Parasitologia Veterinária. $2^{\mathrm{a}}$ ed. Guanabara Koogan, Rio de Janeiro.

VANZOLINI, P.E. 1981. A quasi-historical approach to the natural history of the differentiation of reptiles in tropical geographic isolates. Pap. Avulsos Zool. 34:189-204.

VICENTE, J.J., RODRIGUES, H.O., GOMES, D.C. \& PINTO, R.M. 1991. Nematóides do Brasil, $2^{\mathrm{a}}$ parte: Nematóides de anfíbios. Rev. Bras. Zool 7:549-626. https://doi.org/10.1590/S0101-81751990000400015 (last access on $05 / 05 / 2019$ )

VITT, L.J. \& CALDWELL, J.P. 2009. Herpetology, an introductory biology of amphibians and reptiles. 3 ed. Elsevier, Amsterdam.

VON ZUBEN, C.J. 1997. Implicações da agregação espacial de parasitas para a dinâmica populacional na interação hospedeiro-parasita. Rev. Saúde Pública 31:523-530. https://doi.org/10.1590/S0034-89101997000600014 (last access on $04 / 11 / 2019$ )

Received: $24 / 11 / 2020$

Revised: $18 / 03 / 2021$

Accepted: 31/05/2021

Published online: 05/07/2021 